\title{
A new species of Trichuris Roederer, 1761 (Nematoda: Trichuridae) from Heteromys gaumeri Allen \& Chapman (Rodentia: Heteromyidae) in Yucatan, Mexico
}

\author{
Jesús Alonso Panti-May • María del Rosario Robles
}

Received: 16 March 2016/ Accepted: 5 July 2016

(C) Springer Science+Business Media Dordrecht 2016

\begin{abstract}
In Mexico, four species of Trichuris Roederer, 1761 have been recorded in wild rodents belonging to the family Heteromyidae. In the present paper, we describe a new species based on specimens collected from Heteromys gaumeri Allen \& Chapman (Heteromyidae: Heteromyinae) in the tropical forests of the Yucatan Peninsula, Mexico. Trichuris silviae n. sp. can be differentiated from the congeners described in North and South American rodents by morphological and morphometric features, such as the possession of a wide spicular tube, a thicker proximal cloacal tube, a shorter distal cloacal tube and a cylindrical spicular sheath. This is the first description of a Trichuris spp. from heteromyid rodents in Mexico and the fourth in North America. Despite the broad distribution of Heteromys spp., few cases of Trichuris infection have been reported. Further studies are necessary to verify if the new species is present in other heteromyid rodents in order to increase our knowledge about its geographical and host distribution.
\end{abstract}

\section{J. A. Panti-May ( ()}

PIMVS Tumben Kuxtal A.C., Calle $12 \# 64$ x 5 y 7, C.P. 97470 Tixkokob, Yucatán, Mexico

e-mail: panti.alonso@gmail.com

\section{R. Robles}

Centro de Estudios Parasitológicos y de Vectores

CEPAVE (CCT- CONICET- La Plata), Universidad

Nacional de La Plata (UNLP), Bv 120 e/ 61 y 64, La Plata

(1900), Buenos Aires, Argentina

\section{Introduction}

Species of Trichuris Roederer, 1761 (Nematoda: Trichuridae) have a worldwide distribution and parasitise the large intestine (caecum and colon) of a broad range of mammalian hosts, among which are humans, primates, pigs, horses, and rodents (Cafrune et al., 1999; Anderson, 2000). Characteristics such as the spicular tube, the length of the spicule, the shape of the proximal and distal cloacal tube, and the vulvar morphology, along with classical morphometric data have been used with high discriminatory value for differentiating species of Trichuris (see Špakulová, 1994; Suriano \& Navone, 1994; Rossin \& Malizia, 2005; Robles \& Navone, 2006). Additionally, scanning electron microscopy (Lanfredi et al., 1995; Robles \& Navone, 2006; Robles, 2011; Torres et al., 2011), isoenzyme patterns and molecular tools have been used for species identification (Cutillas et al., 1996, 2002, 2004; Feliu et al., 2000; Callejón et al., 2015).

Until now, 25 species of Trichuris have been described from ten families of North and South American rodents, i.e. the Caviidae, Cricetidae, Ctenomyidae, Dasyproctidae, Echimyidae, Geomyidae, Heteromyidae, Myocastoridae, Octodontidae and Sciuridae. Of these, four species have been recorded in wild rodents with geographical distributions that include central Mexico: Trichuris citelli Chandler, 1945 from Spermophilus variegatus Erxleben in 
Michoacan (García-Prieto et al., 2012); T. dipodomis Read, 1956 from Dipodomys phillipsii Gray in Veracruz (García-Prieto et al., 2012); T. elatoris Pfaffenberger \& Best, 1989 from D. ordii Woodhouse, D. merriami Mearns and Chaetodipus hispidus Baird in San Luis Potosi (García-Prieto et al., 2012); and T. fossor Hall, 1916 from Peromyscus difficilis Allen in Hidalgo (Falcon-Ordaz, 1993) and Liomys irroratus Gray in Morelos (Eslava-Araujo, 2005). Trichuris fossor is the only species recorded from Mexican rodents of the subfamily Heteromyinae (see EslavaAraujo, 2005).

Moreover, a cosmopolitan species, T. muris Schrank, 1788, has been recorded previously for Rattus norvegicus Berkenhout and $R$. rattus Linnaeus in the Distrito Federal (Zerecero, 1943; García-Prieto et al., 2012), Mus musculus L. from Hidalgo (PulidoFlores et al., 2005) and Yucatan (Panti-May et al., 2015), and from L. irrotatus in Morelos (EslavaAraujo, 2005).

Heteromys gaumeri Allen \& Chapman, is a medium-sized rodent endemic to the Yucatan Peninsula (Schmidt et al., 1989). Its geographic range includes northern Belize, El Petén in Guatemala, and southeastern Mexico (Schmidt et al., 1989). In Mexico, H. gaumeri occurs from tall to short semideciduous tropical forest (Pozo de la Tijera \& Escobedo Cabrera, 1999; Hernández-Betancourt et al., 2003; Cimé-Pool et al., 2010; Canul-Cruz et al., 2012), secondary deciduous forest (Dowler \& Engstrom, 1984) and cultivated fields (Birney et al., 1974; Cimé-Pool et al., 2007), where the predominant climate is warm sub-humid with summer rains (Instituto Nacional de Estadística y Geografía, 2015). Heteromys gaumeri plays a key role in the ecology of seed dispersal in tropical forests through harvesting and eating seeds (Hernández-Betancourt et al., 2003; Canul-Cruz et al., 2012).

This paper describes a new species of Trichuris based on specimens collected from Heteromys gaumeri (Heteromyidae: Heteromyinae) from tropical forests in Yucatan, Mexico.

\section{Materials and methods}

Seven specimens of H. gaumeri, six from the Rancho Hobonil of the Universidad Autónoma de Yucatán (UADY), Municipality of Tzucacab and one from the
Facultad de Medicina Veterinaria y ZootecniaUADY, Municipality of Merida, Yucatan State, Mexico, were captured between March and October 2013 (see collectors in acknowledgements). Captured rodents were transported to the laboratory and were euthanised with an intraperitoneal injection of sodium pentobarbital. The abdominal cavities and viscera of the hosts were examined for parasites. Nematodes were collected from the caecum and 15 specimens were fixed in $10 \%$ formalin, preserved in $70 \%$ ethanol, cleared in lactophenol for light microscopy.

Drawings were made with the aid of a drawing tube. One male specimen was dehydrated in ethanol series ( 75 , $80,85,90,96$ and $100 \%$ ), dried using the critical point method, and examined with the aid of a scanning electron microscope (SEM, Jeol 6360 LVLV, Tokyo, Japan).

Measurements are presented as follows: holotype male/allotype female and paratypes, mean and range (in parentheses). All measurements are in micrometres unless otherwise stated. Morphological analysis was performed according Robles et al. (2006), followed in a series of communications (Robles \& Navone, 2006; Robles, 2011; Robles et al., 2014). The type-material is deposited in the Helminthological Collection of the Museo de La Plata, La Plata, Buenos Aires, Argentina and in the Colección Nacional de Helmintos of the Instituto de Biología-Universidad Nacional Autónoma de Mexico, Mexico City, Mexico. Hosts are deposited in the Mastozoological Collections of the Museo de Zoología (MZ)-UADY, Mérida, Yucatan, Mexico.

\section{Order Enoplida Filipjev, 1929 \\ Family Trichuridae Railliet, 1915}

\section{Trichuris silviae n. sp.}

Type-host: Heteromys gaumeri (Allen \& Chapman) (Mammalia: Castorimorpha: Heteromyidae), Gaumer's spiny pocket mouse.

Host vouchers: Symbiotype (female, coll. 27.ix.2013; accession number MZ 1025); other host vouchers (coll. 25-27.ix.2013) housed at the MZ under accession numbers MZ1022-1024 and MZ1009.

Type-locality: Rancho Hobonil (2101'41.8”N, $\left.89^{\circ} 00 ' 51.2^{\prime} \mathrm{W}\right)$, Municipality of Tzucacab, Yucatan State, Mexico.

Other locality: Facultad de Medicina Veterinaria y Zootecnia $\left(20^{\circ} 52^{\prime} 06.5^{\prime \prime} \mathrm{N}, 89^{\circ} 37^{\prime} 04.5^{\prime \prime} \mathrm{W}\right)$, Municipality of Merida, Yucatan State. 
Type-material: Holotype male (MLP-He 7113), allotype female (MLP-He 7114), 12 paratype specimens (MLP-He 7115, CNHE 9987) deposited in the Helminthological Collection of the Museo de La Plata (MLP-He) and in the Colección Nacional de Helmintos (CNHE) of the Instituto de Biología-Universidad Nacional Autónoma de Mexico, Mexico City, Mexico. Site in host: Caecum.

Prevalence and intensity: Overall prevalence $85.7 \%$ (6 infected out of 7 rodents examined); overall intensity 1-45 (mean 12) nematodes; type-locality: prevalence $83.3 \%$ (5 out of 6 hosts infected), mean intensity $14.4(1-45)$.

Etymology: This species is dedicated to Dr. Silvia Hernández Betancourt, a well-known mammalogist in Mexico who has contributed to increasing the knowledge of rodent ecology, particularly in the Yucatan Peninsula.

\section{Description (Figs. 1-2)}

General. [Based on the holotype, allotype and 12 paratypes.] Cuticle with fine transversal striation. Anterior part of body long, narrow, tapered, whip-like; posterior part of body broad, handle-like (Fig. 1A). Ratio between anterior and posterior body length 0.97:1-1.26:1 in males and 0.90:1-1.12:1 in females. Stichosome with single row of stichocytes, and single pair of conspicuous cells at level of oesophago-intestinal junction (Fig. 1B, C). Male with wide spicular tube. Proximal cloacal tube united laterally to distal cloacal tube (Fig. 1D). Spicular sheath cylindrical with spines distributed from proximal to distal portion; distal spines sharpened and joined together (Figs. 1E, 2D). Testis reaches to near first fith of proximal cloacal tube (Fig. 1A, arrow). Cloaca subterminal, not ornamented. Female with non-protrusive vulva located at level of oesophago-intestinal junction (Fig. 1C). Anus subterminal; caudal end long (Fig. 1F).

Bacillary band located laterally in anterior portion of body (Fig. 2A, B), at 80-1,000 from anterior end of body, extending to widened part of body 100-190. Cuticular inflations bordering bacillary band 170-210 from anterior end of body, extend to 640-700 from anterior end, forming low rings of thick walls and very reduced interior cavity (Fig. 2B). These structures limit laterally to abundant, visible bacillary glands with conspicuous pore (Fig. 2B, C,). Cuticle around vulvar aperture with transversally striated pattern.
Male. [Based on the holotype and 9 paratypes.] Body length 13.89 ; 16.61 (14.95-18.71) mm. Anterior portion of body $7.27 ; 8.76(7.67-9.87) \mathrm{mm}$ long; thick portion of body $6.62 ; 7.85$ (6.78-9.43) $\mathrm{mm}$ long (Fig. 1A). Anterior body width 82; 93 (85-110); maximum posterior body width $330 ; 300$ (260-330); width at level of oesophago-intestinal junction 240; 210 (200-230) (Fig. 1B). Total length of oesophagus 7.27; 8.76 (7.67-9.87) mm, muscular portion 590; 560 (470-780) long, stichosome portion $6.68,8.20$ (7.16-9.09) $\mathrm{mm}$ long. Spicule tube length 610 , 570 (470-640). Spicule total length 1,360; $1,390(1,300-1,480)$; width $15 ; 15(15-19)$ at tip, $30 ; 29(25-30)$ at midregion, and 50; $40(30-50)$ at base (Fig. 1D). Spicular sheath, when fully extruded, densely spinose $120 ; 80$ (80-130) long (Fig. 1E). Proximal cloacal tube 1,270; 1,570 (1,410-1,730) long, 190; 190 (140-220) wide; distal cloacal tube 550; 670 (550-940) long, 100; 90 (70-120) wide (Fig. 1D). Ratio total body length/ posterior portion length $2.10 ; 2.12$ (1.97-2.26). Ratio posterior portion length/ anterior portion length 0.9 ; 0.90 (0.80-1.03). Ratio total body length/ spicule length $10.25 ; 11.97$ (10.68-14.37). Ratio posterior portion length/ spicule length $4.89 ; 5.66$ (4.99-7.28). Ratio proximal cloacal tube length/ distal cloacal tube length $2.32 ; 2.41$ (1.79-2.97). Ratio maximum posterior body width/ posterior portion length $0.05 ; 0.04$ (0.03-0.04).

Female. [Based on the allotype and 4 paratypes.] Body length $34.11 ; 23.86(22.14-26.13) \mathrm{mm}$. Anterior portion of body 17.47 ; 12.15 (11.17-13.81) mm long; thick portion of body $16.64 ; 11.71(10.64-12.44) \mathrm{mm}$ long. Anterior body width 130; 110 (90-130); maximum posterior body width 550; 380 (380-400); width at level of oesophago-intestinal junction 300; 200 (190-220) (Fig. 1C). Total length of oesophagus 17.35 ; 12.15 (11.17-13.81) $\mathrm{mm}$, muscular portion 640; 520 (400-620) long, stichosome portion 16.71; 11.62 (10.56-13.42) mm long. Distance between oesophago-intestinal junction and vulva $0.25(0-50)$ (Fig. 1C). Eggs oval, flat, with bipolar plugs $61-65 \times$ 30-31 ( $=4$ ) (Fig. 1G). Ratio total body length/ posterior portion length 2.05; 2.04 (1.90-2.12). Ratio posterior portion length/ anterior portion length $0.95 ; 0.97$ (0.90-1.11). Ratio maximum posterior body width/ posterior portion length $0.03 ; 0.03$ (0.03-0.04). 

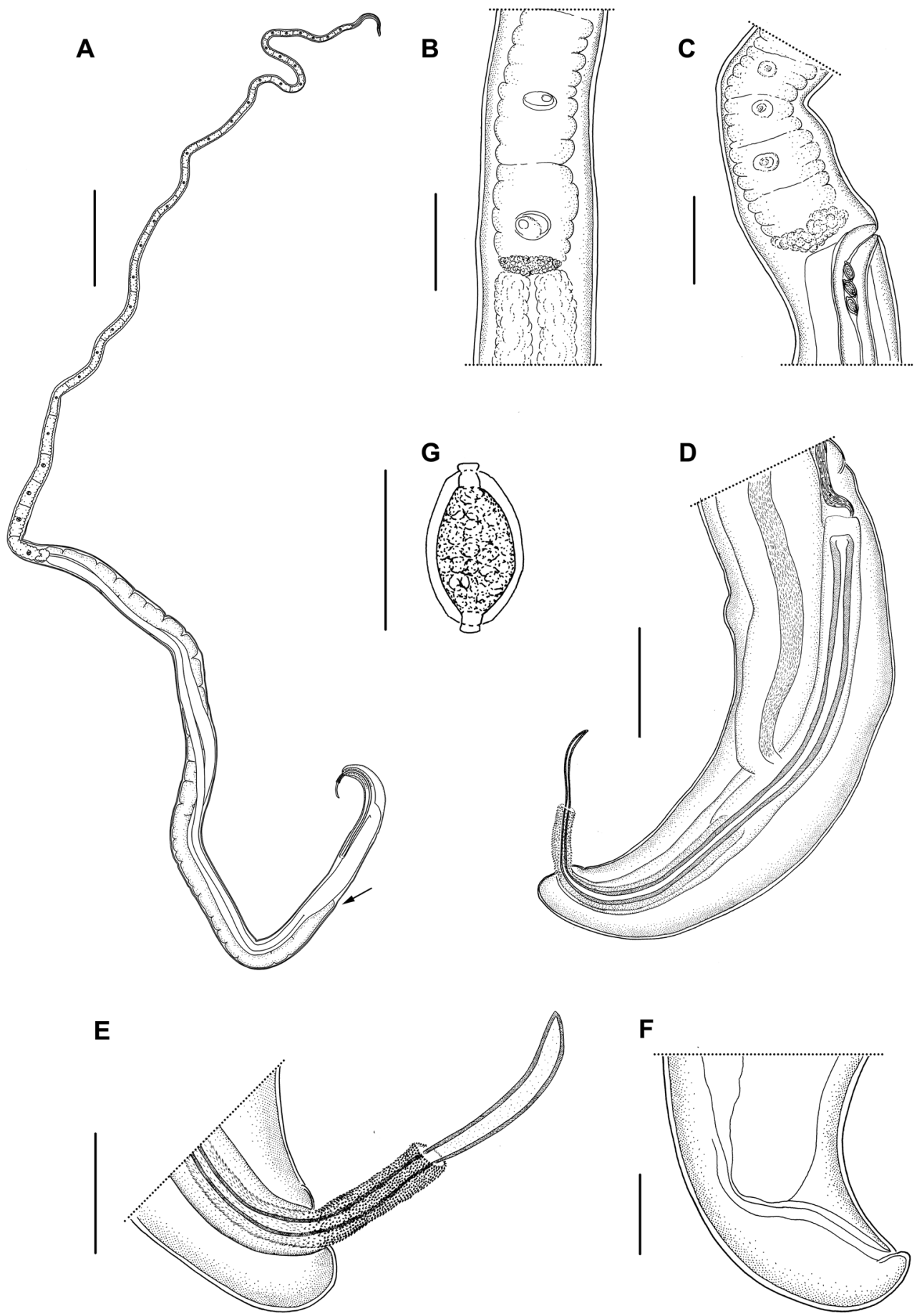

Fig. 1 Trichuris silviae n. sp. ex Heteromys gaumeri. A, Male, total view (arrow indicates posterior extremity of the testis); B, Male, oesophago-intestinal junction and proximal portion of the testis, lateral view; C, Female, oesophago-intestinal junction and vulva, lateral view; D, Male, posterior extremity, spicule, spicular tube, proximal and distal cloacal tube, and spiny spicular sheath, lateral view; E, Male, detail of the posterior extremity and spiny spicular sheath, lateral view; F, Female, posterior extremity, lateral view; G, Egg. Scale-bars: A, 1,000 $\mu \mathrm{m}$; B-D, $200 \mu \mathrm{m} ; \mathrm{E}, \mathrm{F}, 100 \mu \mathrm{m} ; \mathrm{G}, 60 \mu \mathrm{m}$ 
Remarks

Trichuris silviae n. sp. was compared with 25 species of Trichuris described from North and South American rodents (Chandler, 1945; Tiner, 1950; Cameron \& Reesal, 1951; Morini et al., 1955; Read, 1956; Frandsen \& Grundmann, 1961a; Todd \& Lepp, 1972; Babero et al., 1975; Barus et al., 1975; Babero et al., 1976; Babero \& Murua, 1987; Pfaffenberger \& Best, 1989; Babero \& Murua, 1990; Gomes et al., 1992; Suriano \& Navone, 1994; Robles et al., 2006; Robles, 2011; Torres et al., 2011; Robles et al., 2014). Trichuris silviae $\mathrm{n}$. sp. differs from 12 species parasitic in American rodents, i.e. T. opaca Barker \& Noyes, 1915, T. myocastoris Enigk, 1933, T. bursacaudata
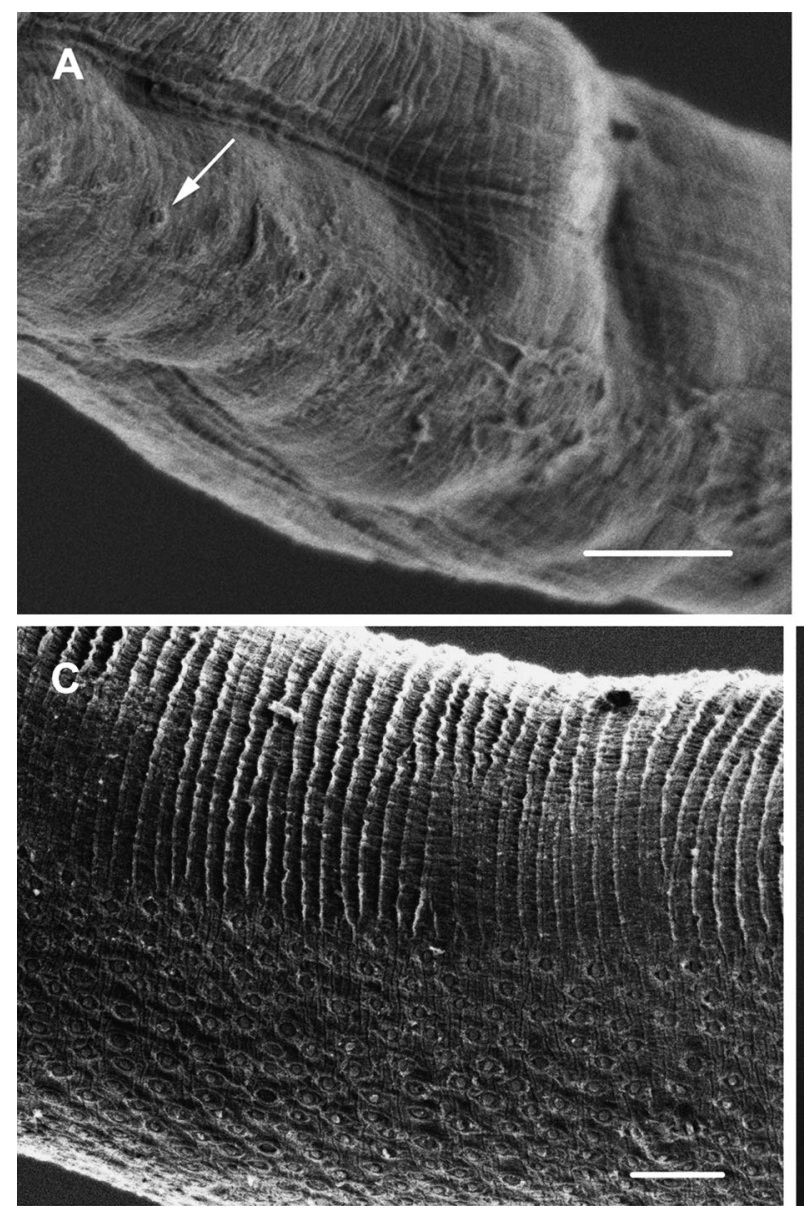

Suriano \& Navone, 1994, T. pampeana Suriano \& Navone, 1994, T. pardinasi Robles, Navone \& Notarnicola, 2006, T. navonae Robles, 2011, T. bradleyi Babero, Cattan, \& Cabello, 1975, T. chilensis Babero, Cattan \& Cabello, 1976, T. elatoris, T. robusti Babero \& Murua, 1990, T. travassosi Correa, Lanfredi, Pinto \& Souza, 1992, and T. bainae Robles, Cutillas, Panei \& Callejón, 2014, by the presence of a spicular tube (in these 12 species, the spicule lies entirely within the distal cloacal tube).

Among the 11 species with spicular tube (i.e. $T$. citelli, T. perognathi Chandler, 1945, T. neotomae Chandler, 1945, T. peromysci Chandler, 1946, T. madisonensis Tiner, 1950, T. fossor, T. dipodomis, $T$. fulvi Babero \& Murua, 1987, T. laevitestis Suriano \&
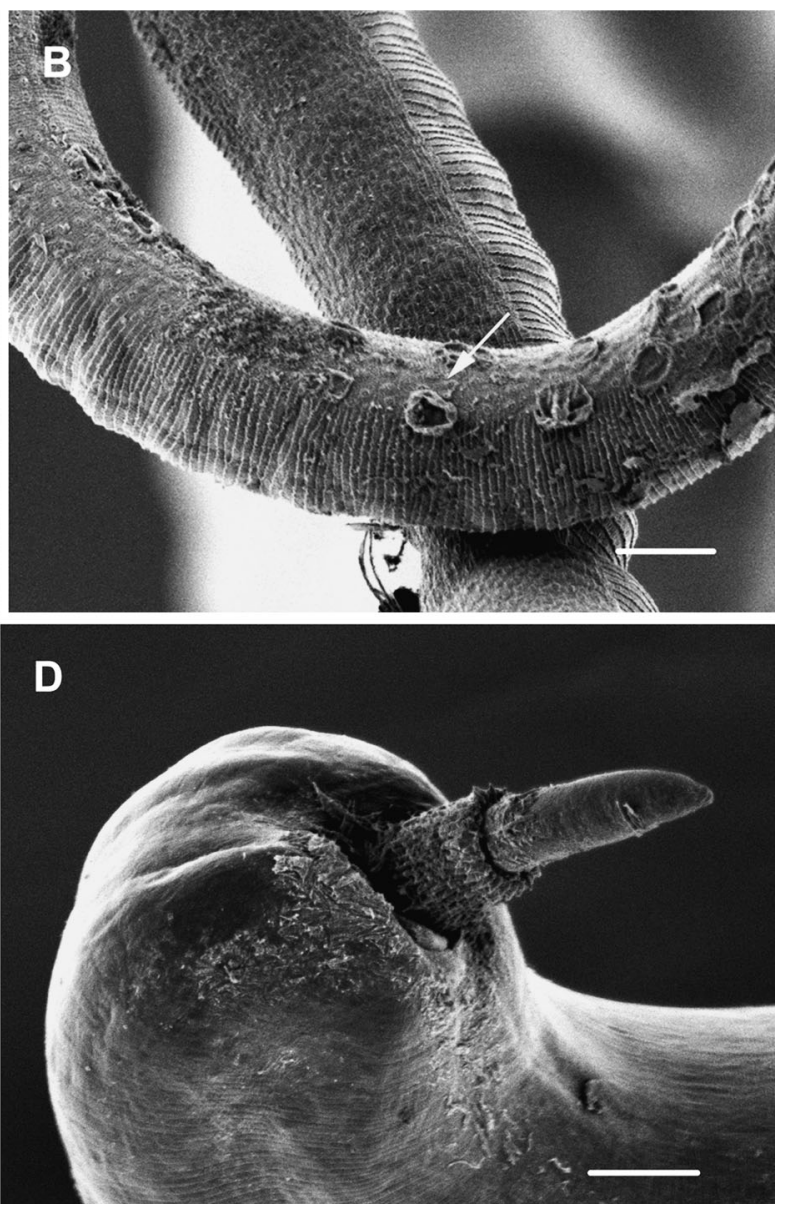

Fig. 2 Scanning electron micrographs of Trichuris silviae n. sp. ex Heteromys gaumeri. A, Detail of bacillary glands (arrow) in the proximal portion of bacillary band; B, Cuticular inflations (arrow) bordering the bacilar band in its proximal portion; C, Detail of bacilary glands in the distal portion of the bacillary band; D, Male, posterior extremity and spiny spicular sheath, ventro-lateral view. Scale-bars: A, C, $10 \mu \mathrm{m} ; \mathrm{B}, \mathrm{D}, 20 \mu \mathrm{m}$ 
Navone, 1994, T. stansburyi Frandsen \& Grundmann, 1961, and T. thrichomysi Torres, Nascimento, Menezes, Garcia, Santos, Maldonado, Miranda, Lanfredi \& Souza, 2011) the new species can be differentiated from T. fossor, T. fulvi, T. laevitestis, and $T$. thrichomysi in having a shorter spicular tube; no data for the remaining species are available. Table 1 shows comparative data highlighting the main distinctive features (i.e. spicular length, spicular sheath shape and distal cloacal tube length) of $T$. silviae $\mathrm{n}$. sp. in relation to the congeners described with a spicular tube described from North and South American rodents.

The new species can be separated from T. opaca, $T$. fossor, $T$. citelli, T. neotomae, $T$. dipodomis and $T$. bursacaudata by the presence of a cylindrical spicular sheath. Among species with a cylindrical spicular sheath, the new species differs from $T$. laevitestis, $T$. thrychomysi, T. pampeana, T. pardinasi, T. navonae, T. elatoris, and $T$. bainae by the distribution and shape of spines and from T. peromysci, T. fulvi, T. stansburyi, $T$. bradleyi, and $T$. robustis by the length of the spicular sheath.

The new species has a shorter spicule than $T$. myocastoris, T. fulvi, T. laevitestis, T. thrichomysi, $T$. bursacaudata, T. pampeana, T. pardinasi, T. bradleyi, T. chilensis, $T$. robusti, T. travassosi and T. bainae and a longer spicule than $T$. perognathi, $T$. neotomae, $T$. madisonensis, T. stansburyi and T. elatoris. Moreover, T. silviae n. sp. has a shorter distal cloacal tube than $T$. citelli, T. myocastoris, T. bursacaudata, T. pampeana, T. pardinasi, T. navonae, T. bradleyi, T. chilensis, $T$. robusti, $T$. travassosi and $T$. bainae and a longer distal cloacal tube than $T$. perognathi and $T$. peromysci.

Although males of T. gracilis Rudolphi, 1819 and T. dolichotis Morini, Boero \& Rodrigues, 1955 have not been described, females of $T$. gracilis can be separated from the new species by the length of the body (38.5-39.6 vs 22.1-34.1 mm), the length of the anterior portion of the body (21.5-27.4 vs 11.2-17.5 $\mathrm{mm})$ and the size of the eggs $(50-59 \times 23-28$ vs 61-65 $\times 30-31 \mu \mathrm{m})$, and females of $T$. dolichotis differ by the ratio posterior portion/ anterior portion of body length (1.33 vs $0.90-1.11)$ and the size of the eggs (75 $\times 45$ vs $61-65 \times 30-31 \mu \mathrm{m})$.

Females of $T$. silviae $\mathrm{n}$. sp. have a smaller distance from the oesophago-intestinal junction to vulva than $T$. madisonensis, T. gracilis, T. fulvi, T. bradleyi, T. chilensis, T. elatoris and T. bainae. In addition, the vulva of the new species is distinguishable from $T$. citelli, T. perognathi, T. neotomae, $T$. gracilis, $T$. dipodomis, T. leavitestis, T. stansburyi, T. chilensis and $T$. bainae by the lack of a marked prominence or evagination.

Most morphometric features of $T$. silvae n. sp. overlap with $T$. peromysci. However, the new species has a longer distal cloacal tube (550-940 vs $380-530 \mu \mathrm{m})$ and shorter spicular sheath $(80-130 \mathrm{vs}$ 260-360 $\mu \mathrm{m})$. Females of T. silviae n. sp. also have smaller eggs $(61-65 \times 30-31$ vs $87-90 \times 40 \mu \mathrm{m})$.

A comparison of the length of the bacillary bands, and the size, shape and distribution of the bacillary glands, as well as their number, with respect to the transversal cuticular striations, showed some differences with other species previously studied under SEM such as T. myocastoris, T. travassosi, T. pampeana, T. pardinasi, T. laevitestis, T. navonae and T. bainae. The bacillary band of $T$. silviae $\mathrm{n}$. sp. begins anteriorly to that reported for $T$. laevitestis, but is similar to the remainig species. The cuticular inflations of the new species form low walls and narrow rings and appear to have a lower density than those observed in other species (Gomes et al., 1992; Lanfredi et al., 1995; Rossin \& Malizia, 2005; Robles \& Navone, 2006; Robles et al., 2006; Robles, 2011; Robles et al., 2014). Although there may be an effect of the preparation of the material, this observation was confirmed under light microscope.

\section{Discussion}

Twenty-six species of Trichuris have been described in American rodents, considering the new species. Although the ranges of some morphometric features overlap among these species and some of them share morphological characteristics, the combination of these characters allows species differentiation. The unique features of $T$. silviae n. sp., such as the presence of a wide spicular tube, a thicker proximal cloacal tube, a shorter distal cloacal tube, a cylindrical spicular sheath with sharp and joined together spines, a non-protrusive vulva, and different morphometric characters and ratios, in combination, support the distinct status of this species.

Althougth the original description of the species of Trichuris described in heteromyids (i.e. T. dipodomis, T. elatoris and T. perognathi) or recorded in Mexican rodents (e.g. T. citelli and T. fossor) are incomplete, 
Table 1 Comparative data for the main distinctive features between Trichuris silviae n. sp. (highlighted in bold) and other Trichuris spp. with spicular tube described from North and South American rodents

\begin{tabular}{|c|c|c|c|c|}
\hline Species & Type-host (Family) & Type-locality & Length or shape & Reference \\
\hline \multicolumn{5}{|l|}{$\begin{array}{l}\text { Spicule }(1,300-1,480 \\
\mu \mathrm{m})\end{array}$} \\
\hline $\begin{array}{l}\text { T. neotomae Chandler, } \\
1945\end{array}$ & $\begin{array}{l}\text { Neotoma fuscipes Baird } \\
\text { (Cricetidae) }\end{array}$ & $\begin{array}{l}\text { Hastings Natural History } \\
\text { Reservation, California, } \\
\text { USA }\end{array}$ & $1,150-1,230$ & Chandler (1945) \\
\hline $\begin{array}{l}\text { T. perognathi } \\
\text { Chandler, } 1945\end{array}$ & 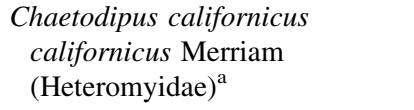 & $\begin{array}{l}\text { Hastings Natural History } \\
\text { Reservation, California, } \\
\text { USA }\end{array}$ & $900-1,150$ & Chandler (1945) \\
\hline $\begin{array}{l}\text { T. madisonensis Tiner, } \\
1950\end{array}$ & Tamias striatus L. (Sciuridae) & Madison, Wisconsin, USA & $830-950$ & Tiner (1950) \\
\hline $\begin{array}{l}\text { T. stansburyi Frandsen } \\
\text { \& Grundmann, } 1961\end{array}$ & $\begin{array}{l}\text { Peromyscus maniculatus } \\
\text { sonoriensis Le Conte } \\
\text { (Cricetidae) }\end{array}$ & Stansbury Island, Utah, USA & $860-1,160$ & $\begin{array}{l}\text { Frandsen \& } \\
\text { Grundmann } \\
\text { (1961a) }\end{array}$ \\
\hline $\begin{array}{l}\text { T. fulvi Babero \& } \\
\text { Murua, } 1987\end{array}$ & $\begin{array}{l}\text { Ctenomys fulvus phillipiensis } \\
\text { Philippi (Ctenomyidae) }\end{array}$ & $\begin{array}{l}\text { San Pedro Atacama, } \\
\text { Tarapaca, Chile }\end{array}$ & $3,470-3,710$ & $\begin{array}{l}\text { Babero \& Murua } \\
\text { (1987) }\end{array}$ \\
\hline $\begin{array}{l}\text { T. laevitestis Suriano } \\
\text { \& Navone, } 1994\end{array}$ & $\begin{array}{l}\text { Scapteromys aquaticus Thomas } \\
\text { (Cricetidae) }\end{array}$ & $\begin{array}{l}\text { Punta Lara, Buenos Aires, } \\
\text { Argentina }\end{array}$ & $3,000-3,650$ & $\begin{array}{l}\text { Suriano \& } \\
\text { Navone (1994) }\end{array}$ \\
\hline $\begin{array}{l}\text { T. thrichomysi Torres } \\
\text { et al., } 2011\end{array}$ & $\begin{array}{l}\text { Thrichomys apereoides Lund } \\
\text { (Echimyidae) }\end{array}$ & $\begin{array}{l}\text { Capitão Andrade, Minas } \\
\text { Gerais, Brazil }\end{array}$ & $1,860-2,780$ & $\begin{array}{l}\text { Torres et al. } \\
\text { (2011) }\end{array}$ \\
\hline \multicolumn{5}{|l|}{$\begin{array}{l}\text { Distal cloacal tube } \\
(550-940 \mu \mathrm{m})\end{array}$} \\
\hline $\begin{array}{l}\text { T. peromysci Chandler, } \\
1946\end{array}$ & $\begin{array}{l}\text { Peromyscus californicus Gambel } \\
\text { (Cricetidae) }\end{array}$ & $\begin{array}{l}\text { Hastings Natural History } \\
\text { Reservation, California, } \\
\text { USA }\end{array}$ & $370-520$ & Chandler (1946) \\
\hline $\begin{array}{l}\text { T. citelli Chandler, } \\
1945\end{array}$ & $\begin{array}{l}\text { Spermophilus beecheyi } \\
\text { Richardson (Sciuridae) }^{\mathrm{b}}\end{array}$ & $\begin{array}{l}\text { Hastings Natural History } \\
\text { Reservation, California, } \\
\text { USA }\end{array}$ & $1,000-1,300$ & Chandler (1945) \\
\hline \multicolumn{5}{|l|}{$\begin{array}{l}\text { Cylindrical spicular } \\
\text { sheath with spines }\end{array}$} \\
\hline T. fossor Hall, 1916 & $\begin{array}{l}\text { Thomomys talpoides Allen } \\
\text { (Geomyidae) }^{\text {c }}\end{array}$ & $\begin{array}{l}\text { Crested Buttes and } \\
\text { Livermore, Colorado, USA }\end{array}$ & $\begin{array}{l}\text { With distal } \\
\text { spherical bulge } \\
\text { and spiny }\end{array}$ & Hall (1916) \\
\hline $\begin{array}{l}\text { T. dipodomis Read, } \\
1956\end{array}$ & $\begin{array}{l}\text { Dipodomys ordii Woodhouse } \\
\text { (Heteromyidae) }\end{array}$ & Santa Fe, New Mexico, USA & $\begin{array}{l}\text { Campanuliform } \\
\text { and spiny }\end{array}$ & Read (1956) \\
\hline
\end{tabular}

${ }^{\mathrm{a}}$ Cited as Perognathus californicus californicus; ${ }^{\mathrm{b}}$ Cited as Citellus beecheyi; ${ }^{\mathrm{c}}$ Cited as Thomomys fossor

these species are well distinguished when compared with T. silviae n. sp. However, furher revisions are needed to clarify some morphological features (e.g. distal cloacal tube) of these Trichuris spp. for which no drawings and/or photos are provided in their original descriptions.

The bacillary band of $T$. silviae $\mathrm{n}$. sp. was studied under light microscopy, and only a few studies include SEM descriptions of this structure. Although fixation can alter the structure of the bacillary bands (Wright, 1975), in the new species the bands appear to be very well conserved, showing some differences in the distribution of the glands, and different sizes and shapes of the cuticular inflations compared to those observed in six other studied species (Gomes et al., 1992; Lanfredi et al., 1995; Rossin \& Malizia, 2005; Robles \& Navone, 2006; Robles et al., 2006; Robles, 2011). Since the bacillary bands are not known for all Trichuris spp., it is possible that the importance of this structure will be assessed only when new studies with detailed descriptions, illustrations, and photographs are provided. 
The type-host of $T$. silviae n. sp., H. gaumeri, belongs to a genus of Neotropical hosts, abundant from southern Mexico to Ecuador, Colombia and Venezuela (Rogers \& González, 2010). However, information on species of Trichuris parasitising Heteromys spp. is scarse. In Mexico, no previous study has reported the presence of Trichuris spp. in Heteromys spp. Considering heteromyid hosts, only $T$. dipodomis, T. elatoris, T. fossor and T. muris have been reported in Mexico (Eslava-Araujo, 2005; García-Prieto et al., 2012).

The geographical distribution of $H$. gaumeri (Yucatan Peninsula) does not overlap with areas where other wild rodent hosts of Trichuris spp. have been recorded (Falcon-Ordaz, 1993; Eslava-Araujo, 2005; García-Prieto et al., 2012). In Costa Rica, a Trichuris sp. has been reported in H. desmarestianus Gray (Chinchilla-Carmona et al., 2013). Further studies are necessary to verify if the new species occurs in other sympatric rodents in order to increase our knowledge on its geographical and host distribution.

Trichuris silviae $\mathrm{n}$. $\mathrm{sp}$. is the first species described from heteromyids in Mexico and the fourth in North America (Chandler, 1945; Read, 1956; Pfaffenberger \& Best, 1989). Also, this is the sixth record of Trichuris spp. from rodents in Mexico, including the cosmopolitan T. muris recorded in native and nonnative rodents (Eslava-Araujo, 2005; García-Prieto et al., 2012). The family Heteromyidae consists of six genera (Chaetodipus Merriam, Dipodomys Gray, Heteromys, Liomys Merriam, Microdipodops Merriam and Perognathus Wied-Neuwied) with more than 57 species distributed from Canada to Ecuador (Alexander \& Riddle, 2005). The helminth fauna of heteromyids comprises more than sixteen nematode genera (see Read \& Millemann, 1953; Grundmann, 1957; Frandsen \& Grundmann, 1961b; Decker et al., 2001; Falcon-Ordaz \& García-Prieto, 2005).

Among heteromyids, Chaetodipus formosus Merriam, C. hispidus, C. californicus, C. penicillatus Woodhouse, Dipodomys deserti Stephens, D. merriami, D. microps Merriam, D. ordii, D. phillipsii, D. spectabilis Merriam, H. desmarestianus and L. irroratus have been reported as hosts of Trichuris spp. from Costa Rica, Mexico, and USA (Doran, 1955; Grundmann, 1957; Munger \& Slichter, 1995; Decker et al., 2001; García-Prieto et al., 2012; ChinchillaCarmona et al., 2013). Additional field studies could determine if Trichuris spp. occur in other heteromyids rodents.

Acknowledgements We would like to thank to Drs Silvia Hernández-Betancourt and Marco Torres-Castro for their support in the field work, to the staff of the Laboratorio de Parasitología-FV-UADY, Mexico for their help; to Erendira Martínez for her support in the Laboratorio de Zoología-FVUADY; to Dr. Graciela Navone for her support in the Laboratorio de Parasitología-CEPAVE, Argentina; to Josh Taylor for the critical reading of the manuscript and for the revision to English, and to two anonymous referees for their valuable suggestions to improve this paper.

Funding Fieldwork was partly supported by the FOMIXCONACYT FOMIX-YUC-2008-108929 (Sensibilidad y vulnerabilidad de los ecosistemas costeros del sureste de México ante el Cambio Climático Global). MRR is member of CONICET.

\section{Compliance with ethical standards}

Conflict of interest The authors declare that they have no conflict of interest.

Ethical approval All applicable institutional, national and international guidelines for the care and use of animals were followed. Host capture was conducted under license from Mexican Ministry of Environment (SGPA/DGVS/02528/13).

\section{References}

Alexander, L. F., \& Riddle, B. R. (2005). Phylogenetics of the new world rodent family Heteromyidae. Journal of Mammalogy, 86, 366-379.

Anderson, R. C. (2000). Nematode parasites of vertebrates: Their development and tranmission. 2nd edition. Wallingford, Oxon: CAB International, $650 \mathrm{pp}$.

Babero, B. B., Cattan, P. E., \& Cabello, C. (1975). Trichuris bradleyi sp. n., a whipworm from Octodon degus in Chile. Journal of Parasitology, 61, 1061-1063.

Babero, B. B., Cattan, P. E., \& Cabello, C. (1976). A new species of whipworm from the rodent Akodon longipilis in Chile. Transactions of the American Microscopical Society, 95, 232-235.

Babero, B. B., \& Murua, R. B. (1987). The helminth fauna of Chile. X. A new species of whipworm from a Chilean rodent. Transactions of the American Microscopical Society, 106, 190-193.

Babero, B. B., \& Murua, R. B. (1990). A new species of whipworm from a South American hystricomorph rodent. Memorias do Instituto Oswaldo Cruz, 85, 211-213.

Barus, V., Majumdar, G., \& Mikailov, T. K. (1975). Morphology and taxonomy of Trichocephalus myocastoris (Enigk, 1933). Folia Parasitologica, 22, 207-213.

Birney, E. C., Bowles, J. B., Timm, R. M., \& Williams, S. L. (1974). Mammalian distributional records in Yucatan and 
Quintana Roo, comments on reproduction, structure, and status on peninsular populations. Occasional Papers of the Bell Museum of Natural History University of Minnesota, 13, 1-25.

Cafrune, M. M., Aguirre, D. H., \& Rickard, L. G. (1999). Recovery of Trichuris tenuis Chandler, 1930, from camelids (Lama glama and Vicugna vicugna) in Argentina. Journal of Parasitology, 85, 961-962.

Callejón, R., Cutillas, C., \& Nadler, S. A. (2015). Nuclear and mitochondrial genes for inferring Trichuris phylogeny. Parasitology Research, 114, 4591-4599.

Cameron, T. W. M., \& Reesal, M. R. (1951). Studies on the endoparasitic fauna of Trinidad mammals: VII. Parasites of hystricomorph rodents. Canadian Journal of Zoology, 29, 276-289.

Canul-Cruz, A., Vargas-Contreras, J. A., \& Escalona-Segura, G. (2012). Algunos aspectos poblacionales del ratón de abazones Heteromys gaumeri de la Reserva de la Biosfera Calakmul, Campeche, México. In: Cervantes F. A., \& Ballesteros-Barrera C. (Eds). Estudios sobre la Biología de Roedores Silvestres Mexicanos. Distrito Federal: Universidad Nacional Autónoma de México-Universidad Autónoma Metropolitana, pp. 71-84.

Chandler, A. C. (1945). Trichuris species from California rodents. Journal of Parasitology, 31, 284-286.

Chandler, A. C. (1946). Trichuris peromysci n. sp. from Peromyscus californicus, and further notes on T. perognathi Chandler, 1945. Journal of Parasitology, 32, 208.

Chinchilla-Carmona, M., Valerio-Campos, I., Sanchéz-Porras, R., Martínez-Ezquivel, L., González-Paniagua, A., Valerio-Campos, L., et al. (2013). Parásitos intestinales y sanguíneos de 4 especies de roedores y 5 ejemplares de Philander opossum (Didelphimorpha: Didelphidae) capturados en la Reserva Biológica Alberto Manuel Brenes (REBAMB) de Costa Rica. Revista Ibero-Latinoamericana de Parasitología, 72, 176-184.

Cimé-Pool, J. A., Hernández-Betancourt, S. F., Barrientos, R. C., \& Castro-Luna, A. A. (2010). Diversidad de pequeños roedores en una selva baja caducifolia espinosa del noreste de Yucatán, México. Therya, 1, 23-39.

Cimé-Pool, J. A., Hernández-Betancourt, S. F., \& Chablé-Santos, J. B. (2007). Comunidad de pequeños roedores en dos agroecosistemas del estado de Yucatán, México. Revista Mexicana de Mastozoología, 11, 57-68.

Cutillas, C., German, P., Arias, P., \& Guevara, D. C. (1996). Characterization of Trichuris skrjabini by isoenzyme gel electrophoresis: Comparative study with Trichuris ovis. Acta Tropica, 62, 63-69.

Cutillas, C., Oliveros, R., de Rojas, M., \& Guevara, D. C. (2002). Determination of Trichuris muris from murid hosts and $T$. arvicolae (Nematoda) from arvicolid rodents by amplification and sequentiation of the ITS1-5.8S-ITS2 segment of the ribosomal DNA. Parasitology Research, $88,574-582$.

Cutillas, C., Oliveros, R., de Rojas, M., \& Guevara, D. C. (2004). Determination of Trichuris skrjabini by sequencing of the ITS1-5.8S-ITS2 segment of the ribosomal DNA: Comparative molecular study of different species of trichurids. Journal of Parasitology, 90, 648-652.

Decker, K. H., Duszynski, D. W., \& Patrick, M. J. (2001). Biotic and abiotic effects on endoparasites infecting Dipodomys and Perognathus species. Journal of Parasitology, 87, 300-307.

Doran, D. J. (1955). A catalogue of the protozoa and helminths of North American rodents. III. Nematoda. American Midland Naturalist, 53, 162-175.

Dowler, R. C., \& Engstrom, M. D. (1984). Distributional records of mammals from the southwestern Yucatán Peninsula of México. Annals of Carnegie Museum, 57, 159-166.

Eslava-Araujo, A. G. (2005). Helmintos en la mastofauna silvestre de la Sierra de Monte Negro, Morelos, México. Thesis, Universidad Autónoma del Estado de Morelos, México, 110 pp.

Falcon-Ordaz, J. (1993). Estudio taxonómico de los nemátodos parásitos de roedores de los géneros Peromyscus y Liomys, de Huehuetla y Atlatilpan, Estado de Hidalgo. Thesis, Universidad Nacional Autónoma de México, México, 100 pp.

Falcon-Ordaz, J., \& García-Prieto, L. (2005). A new species of Vexillata (Nematoda: Trichostrongylina: Ornithostrongylidae) parasite of Heteromys desmarestianus (Rodentia: Heteromyidae) from Costa Rica. Journal of Parasitology, 91, 329-334.

Feliu, C., Špakulová, M., Casanova, J. C., Renaud, F., Morand, S., Hugot, J. P., et al. (2000). Genetic and morphological heterogeneity in small rodent whipworms in southwestern Europe: Characterization of Trichuris muris and description of Trichuris arvicolae n. sp. (Nematoda: Trichuridae). Journal of Parasitology, 86, 442-449.

Frandsen, J. C., \& Grundmann, A. W. (1961a). Trichuris stansburyi and Gongylonema mysciphilia, two new species of nematodes from the deer mouse in Utah. Proceedings of the Helminthological Society of Washington, 28, 91-94.

Frandsen, J. C., \& Grundmann, A. W. (1961b). Endoparasitism in isolated populations of rodents of the Lake Bonneville Basin, Utah. Journal of Parasitology, 47, 391-396.

García-Prieto, L., Falcón-Ordaz, J., \& Guzmán-Cornejo, C. (2012). Helminth parasites of wild Mexican mammals: List of species, hosts and geographical distribution. Zootaxa, 92, 1-92.

Gomes, D. C., Lanfredi, R. M., Pinto, R. M., \& de Souza, W. (1992). Description of Trichuris travassosi n. sp. (Nematoda: Trichurinae) from a Brazilian rodent, by light and scanning electron microscopy. Memorias do Instituto Oswaldo Cruz, 87, 1-10.

Grundmann, A. W. (1957). Nematode parasites of mammals of the Great Salt Lake Desert of Utah. Journal of Parasitology, 43, 105-112.

Hall, M. C. (1916). Nematode parasites of mammals of the orders Rodentia, Lagomorpha, and Hyracoidea. Proceedings of the United States National Museum, 50, 1-258.

Hernández-Betancourt, S. F., López-Willchis, R., Cimé-Pool, J. A., \& Medina-Peralta, S. (2003). Área de actividad, movimiento y organización social de Heteromys gaumeri Allen y Chapman, 1897 (Rodentia: Heteromyidae) en una selva mediana subcaducifolia de Yucatán, México. Acta Zoologica Mexicana, 90, 77-91.

Instituto Nacional de Estadística y Geografía (2015). Climatología. www.inegi.org.mx. Accessed 19 Apr 2015.

Lanfredi, R. M., de Souza, W., \& Gomes, D. C. (1995). Comparative study of four species of Trichuris Roederer, 1761 
(Nematoda, Trichuninae) by scanning electron microscopy. Memorias do Instituto Oswaldo Cruz, 90, 489-496.

Morini, E. G., Boero, J., \& Rodriguez, A. (1955). Parásitos intestinales en el Marra (Dolichotis patagonum). Publicación Misión de Estudios de Patalogía Regional Argentina, 26, 83-89.

Munger, J. C., \& Slichter, T. A. (1995). Whipworm (Trichuris dipodomys) infection in kangaroo rats (Dipodomys spp.): Effects on digestive efficiency. Great Basin Naturalist, 55, 74-77.

Panti-May, J. A., Hernández-Betancourt, S. F., Rodríguez-Vivas, R. I., \& Robles, M. R. (2015). Infection levels of intestinal helminths in two commensal rodent species from rural households in Yucatan, Mexico. Journal of Helminthology, 89, 42-48.

Pfaffenberger, G. S., \& Best, T. L. (1989). Trichuris elatoris sp. n. (Nematoda: Trichuridae) from the Texas kangaroo rat (Dipodomys elator). Proceedings of the Helminthological Society of Washington, 56, 76-81.

Pozo de la Tijera, C., \& Escobedo Cabrera, E. (1999). Mamíferos terrestres de la Reserva de la Biosfera de Sian Ka' an, Quintana Roo, México. Revista de Biologia Tropical, 47, 251-262.

Pulido-Flores, G., Moreno-Flores, S., \& Monks, S. (2005). Helminths of rodents (Rodentia: Muridae) from Metztitlán, San Crsitobal, and Rancho Santa Elena, Hidalgo, Mexico. Comparative Parasitology, 72, 186-192.

Read, C. P. (1956). Trichuris dipodomis, n. sp., from Ord's kangaroo rat. Proceedings of the Helminthological Society of Washington, 23, 119.

Read, C. P., \& Millemann, R. E. (1953). Helminth parasites in kangaroo rats. University of California Publications in Zoology, 59, 61-80.

Robles, M. R. (2011). New species of Trichuris (Nematoda:Trichuridae) from Akodon montensis Thomas, 1913, of the Paranaense Forest in Argentina. Journal of Parasitology, 97, 319-327.

Robles, M. R., Cutillas, C., Panei, C. J., \& Callejón, R. (2014). Morphological and molecular characterization of a new Trichuris species (Nematoda-Trichuridae), and phylogenetic relationships of Trichuris species of cricetid rodents from Argentina. PLoS One, 9, e112069.

Robles, M. R., \& Navone, G. T. (2006). Redescription of Trichuris laevitestis (Nematoda: Trichuridae) from Akodon azarae and Scapteromys aquaticus (Sigmodontinae:
Cricetidae) in Buenos Aires Province, Argentina. Journal of Parasitology, 92, 1053-1057.

Robles, M. R., Navone, G. T., \& Notarnicola, J. (2006). A new species of Trichuris (Nematoda: Trichuridae) from Phyllotini rodents in Argentina. Journal of Parasitology, 92, 100-104.

Rogers, D. S., \& González, M. W. (2010). Phylogenetic relationships among spiny pocket mice (Heteromys) inferred from mitochondrial and nuclear sequence data. Journal of Mammalogy, 91, 914-930.

Rossin, M. A., \& Malizia, A. I. (2005). Redescription of Trichuris pampeana (Nematoda: Trichuridae) from the South American subterranean rodent Ctenomys talarum Thomas, 1898 (Rodentia: Octodontidae). Journal of Parasitology, 91, 127-130.

Schmidt, C. A., Engstrom, M. D., \& Genovays, H. H. (1989). Heteromys gaumeri. Mammalian Species, 345, 1-4.

Špakulová, M. (1994). Discriminant analysis as a method for the numerical evaluation of taxonomic characters in male trichurid nematodes. Systematyc Parasitology, 29, 113-119.

Suriano, D. M., \& Navone, G. T. (1994). Three new species of the genus Trichuris Roederer, 1761 (Nematoda: Trichuridae) from Cricetidae and Octodontidae rodents in Argentina. Research and Reviews in Parasitology, 54, 39-46.

Tiner, J. D. (1950). Two new species of Trichuris from North America, with redescriptions of Trichuris opaca and Trichuris leporis (Nematoda: Aphasmidia). Journal of Parasitology, 36, 350-355.

Todd, K. S., \& Lepp, D. L. (1972). Redescription of Trichuris fossor Hall, 1916 (Nematoda: Trichuridae) from the northern pocket gopher, Thomomys talpoides. Proceedings of the Helminthological Society of Washington, 39, 203-205.

Torres, E. J. L., Nascimento, A. P. F., Menezes, A. O., Garcia, J., dos Santos, M. A. J., Maldonado, A., et al. (2011). A new species of Trichuris from Thrichomys apereoides (Rodentia: Echimyidae) in Brazil: Morphological and histological studies. Veterinary Parasitology, 176, 226-235.

Wright, K. A. (1975). Cuticular inflations in whipworms, Trichuris spp. International Journal for Parasitology, 5, 461-463.

Zerecero, M. C. (1943). Algunos helmintos de las ratas domésticas y silvestres de México con descripción de dos nuevas especies. Thesis, Universidad Nacional Autónoma de México, México, 77 pp. 